\title{
Haematopoietic Effects of Amloki (Emblica officinalis) in Pregnancy with Iron Deficiency Anaemia
}

\author{
Tahmina Akter ${ }^{*}$, Qazi Shamima Akhter ${ }^{1}$, Md. Shah Amran², Saima Haque Lisa ${ }^{3}$, \\ Ariza Sultana ${ }^{4}$, Farhana Sultana ${ }^{5}$, Rahnuma Ahmad6, Sayeda Tasnim Kamal', \\ Tamanna Binte Habib ${ }^{1}$, Farhana Rahman ${ }^{1}$
}

\author{
${ }^{1}$ Department of Physiology, Dhaka Medical College and Hospital, Dhaka, Bangladesh \\ ${ }^{2}$ Department of Pharmaceutical Chemistry, University of Dhaka, Dhaka, Bangladesh \\ ${ }^{3}$ Department of Physiology, Parkview Medical College and Hospital, Sylhet, Bangladesh \\ ${ }^{4}$ Department of Physiology, National Institute of Neurosciences and Hospital, Dhaka, Bangladesh \\ ${ }^{5}$ Department of Physiology, Dhaka Community Medical College, Dhaka, Bangladesh \\ ${ }^{6}$ Department of Physiology, Medical College for Women and Hospital, Dhaka, Bangladesh \\ Email: ^tahmina.runa.akter1@gmail.com,shamimaqazi@yahoo.com, amranms@du.ac.bd, saimahaque@gmail.com, \\ arizaali03@gmail.com, farhanatultul16@gmail.com,rahnuma.ahmad@gmail.com, dr.tasnim.n@gmail.com, \\ tamannapompy1234@gmail.com,runa.newlook@gmail.com
}

How to cite this paper: Akter, T., Akhter, Q.S., Amran, Md.S., Lisa, S.H., Sultana, A., Sultana, F., Ahmad, R., Kamal, S.T., Habib, T.B. and Rahman, F. (2020) Haematopoietic Effects of Amloki (Emblica officinalis) in Pregnancy with Iron Deficiency Anaemia. Journal of Biosciences and Medicines, 8, 157-165.

https://doi.org/10.4236/jbm.2020.812015

Received: November 22, 2020

Accepted: December 21, 2020

Published: December 24, 2020

Copyright $\odot 2020$ by author(s) and Scientific Research Publishing Inc. This work is licensed under the Creative Commons Attribution International License (CC BY 4.0).

http://creativecommons.org/licenses/by/4.0/

\begin{abstract}
Due to poverty and ignorance more than half of the pregnant women in developing country are suffering from iron deficiency anaemia (IDA). Different gastrointestinal side effects cause low compliance to iron supplementation. Amloki (Emblica officinalis) is very popular among pregnant women for its taste and traditional belief of well-being. The aim of this study is to determine the effects of amloki on RBC, WBC and Platelet count. Prospective comparative study was carried out on patients of Outpatient Department of Obstetrics and Gynecology, Dhaka Medical College Hospital from July 2016 to June 2017. A total of 43 pregnant women between the 13th to the 20th weeks of gestation with IDA were selected aged 18 - 36 years in this study. Anemic pregnant women supplemented with oral iron and amloki were considered as study group (A) and control group (B) were with only iron supplementation for 45 days. Total count of RBC, WBC and platelet were done in the Department of Hematology \& BMT Unit, Dhaka Medical College Hospital, Dhaka. For statistical analysis, Paired Student's " $t$ " test and Unpaired Student's " $t$ " test were considered using SPSS 22.0 version. A significant increase $(p<0.05)$ of blood RBC count was observed after intervention of iron in both groups. There was also significant increase in RBC count in iron + amloki supplemented group than that of only iron supplemented group. In this study, there
\end{abstract}


was also increase of WBC count in iron + amloki supplemented group and decrease of platelet count in both groups, but these changes were not statistically significant. It can be concluded that oral amloki supplementation causes increased blood RBC count in IDA with pregnancy.

\section{Keywords}

Iron Deficiency Anaemia, Pregnancy, Amloki, RED Blood Cell, White Blood Cell, Platelet

\section{Introduction}

Iron deficiency anaemia (IDA) is one of the most common health problems during pregnancy [1]. Presently available antianaemic preparations to treat IDA in pregnancy have many side effects like nausea, vomiting, heart burn and constipation [2] [3]. So, it would be better to use a natural remedy which has been traditionally used for a long time with less or no side effects. The fruit Emblica officinalis (amloki) is one of the most frequently used ayurvedic herbs [4] [5] [6].

Though iron deficiency anaemia can be diagnosed by patient's history and clinical examination, some laboratory examinations are required to establish the diagnosis. Complete blood count documents the severity of the anaemia. In chronic IDA, the cellular indices show a microcytic and hypochromic erythropoiesis. In $40 \%$ cases, IDA can show normocytic normochromic blood picture [7]. Platelet count may be increased $(>450,000 / \mu \mathrm{L})$; which becomes normal after iron therapy. The white blood cell count may be elevated than the normal range $(4500-11,000 / \mu \mathrm{L})[8]$.

Several studies have been done about IDA in pregnancy in Bangladesh and worldwide. WHO has recommended iron and folic acid supplementation as standard treatment for IDA in pregnancy [9]. But it has several side effects, like heart burn, nausea, upper gastric discomfort, constipation and diarrhea. Some studies have shown to generate free radicles, which cause damage to the intestine [6]. But, amloki has the ability to increase iron absorption and decreases the side effects [10].

Researchers observed the haematological effects of Amloki on both experimental animals and humans. Haque and Sinha (2015) experimented that aqueous extracts of Emblica officinalis fruit administration significantly increases red blood cell, hemoglobin concentration and WBC count in wister albino rats [11].

Amloki is considered one of the richest sources of vitamin C (ascorbic acid). Presence of low molecular weight hydrolysable tannins, prevents the oxidization of ascorbic acid even in dried fruit. So, nutritional qualities of fruit remain unaltered. Scartezzini et al. (2016) found that dried and frozen fruit contains about the same (0.4\%) ascorbic acid, while Ayurvedically processed fruit preparation contains 3 times more (1.28\%) ascorbic acid [12] [13]. 
Non-haem iron predominates in all diets. About 90\% - 95\% of total daily iron intake derived from non-haem iron. The majority of dietary non-haem iron remains in $\mathrm{Fe}^{3+}$ form, which must be reduced to $\mathrm{Fe}^{2+}$ form for its absorption. Vitamin $\mathrm{C}$ present in amloki causes this reduction and increases iron absorption. Combination of amloki with $\mathrm{FeSO}_{4}$ can enhance iron absorption 3 fold over the control iron preparation of $\mathrm{FeSO}_{4}$ alone [14]. Phytates found in cereal products and polyphenolic compounds in all plant products are the most potent dietary inhibitor of non-haem iron absorption. Dietary ascorbic acid can counteract the inhibitory effect of phytates and polyphenol [15]. Adding vitamin C to a meal increases non-heme iron absorption up to six-fold which makes the absorption of non-heme iron as good as or better than that of heme iron [16].

\section{Material and Methods}

This prospective comparative study was carried out on patients of Outpatient Department of Obstetrics and Gynecology, Dhaka Medical College Hospital from July 2016 to June 2017 recruiting 43 pregnant women between the $13^{\text {th }}$ to the $20^{\text {th }}$ weeks of gestation with IDA. All of them were in between 18 - 36 years of age.

1) Study design: Prospective, open labeled interventional study.

2) Study location: This was a tertiary care teaching hospital based study done in Department of Physiology, Dhaka Medical College and Hospital, Dhaka.

3) Sample size calculation: The sample size was estimated on the basis of the difference between two means from previous study. We assumed that the power of the study was $90 \%$ and the level of significance was $5 \%$. The sample size actually obtained for this study was 21 patients for each group. We planned to include 25 patients (Group I-study, Group II-Control of 25 patients for each group) with $16 \%$ drop out rate.

4) Subjects \& selection method: Sample size was divided into two groups.

a) Group A (study group) consisted of 24 pregnant women with IDA, were supplemented with oral amloki capsule (1.072 gm) thrice daily and iron tablet [ferrous fumarate $(200 \mathrm{mg})+$ folic acid $(0.02 \mathrm{mg})$ ] once daily for 45 days. This group was studied two times designated as,

Group $\mathrm{A}_{1}$ : At baseline i.e. before starting intervention.

Group $\mathrm{A}_{2}$ :.After 45 days i.e. after 45 days of intervention.

b) Group B (control group) consisted of 19 pregnant women with IDA, treated with only iron tablet [ferrous fumarate $(200 \mathrm{mg})$ and folic acid (0.20 $\mathrm{mg}$ )] once daily for 45 days. This group was studied two times designated as,

Group $\mathrm{B}_{1}$ : At baseline i.e. before starting intervention.

Group $\mathrm{B}_{2}$ : After 45 days i.e. after 45 days of intervention.

5) Diagnostic criteria

- Signs and symptoms of iron deficiency anaemia.

- Haemoglobin concentration $(\mathrm{Hb}) \geq 8$ to $<11 \mathrm{~g} / \mathrm{dl}$.

- Blood pictures with micocytic hypochromic and normocytic normochromic RBC. 
6) Inclusion criteria:

- Pregnant women between the $13^{\text {th }}$ wk to the $20^{\text {th }}$ wk of gestation.

- Age 18 to 36 yrs.

- Not taking any other drugs.

7) Exclusion criteria:

- Patients having $\mathrm{Hb}<8 \mathrm{~g} / \mathrm{dl}$.

- Patients with a history of anemia due to any conditions like, bleeding piles, PUD, cardiac/renal/liver disorders, DM, HTN, thalassaemia, sickle cell anaemia, rheumatoid arthritis, worm infestation, hemoglobinopathies and malignancy.

- Defective absorption like patients of gastrectomy, gastrojejunostomy, sprue syndrome etc.

- Pregnancy induced complications like hyperemesis gravidarum, antepartum hemorrhage, pre-eclamptic toxaemia, eclampsia, GDM, jaundice. Patients with a history of drug or alcohol abuse.

\section{8) Authentification of amloki capsule}

The amloki capsule (Amlahills) was authentified by the Department of Pharmaceutical Chemistry, Faculty of Pharmacy, University of Dhaka, which was manufactured by Isha Agro Developers PVT.LTD, India.

\section{9) Procedure methodology}

After selection of the subjects, the nature, purpose and benefit of the study were explained to each subject in detail. They were encouraged for voluntary participation. They were allowed to withdraw from the study whenever they feel like. Informed written consent was taken from the participants. The research work was carried out after obtaining ethical clearance from concerned departments, Research Review Committee and Ethical Review Committee of Dhaka Medical College, Dhaka. Before taking blood, detailed family and medical history were taken. Anthropometric measurement of the subjects was done and blood pressure was measured. All the informations were recorded in a prefixed questionnaire. Haematological parameters were estimated in the Department of Haematology \& BMT Unit, Dhaka Medical College Hospital, Dhaka by using automated haematology analyzer Model XT-2000i. These parameters were studied 2 times in all subjects of control and study groups, i.e. at the beginning of the study (baseline) and after 45 days of study period. Compliance to the supplementation was monitored by regular telephonic communications. Amloki capsules were given in boxes for 45 days and participants were encouraged to continue the supplied medicine daily. After 2 weeks of study period one subject was excluded from study group, because she was advised by someone not to take amloki capsule. Within 6 weeks of study, 6 subjects from control group left Dhaka. So, finally 24 subjects of study and 19 subjects of control groups completed the study.

\section{0) Statistical analysis}

All the parameters were expressed as mean \pm SD (standard deviation). Paired 
Student's " $\mathrm{t}$ " test and Unpaired Student's " $\mathrm{t}$ " test were used as the test of significance as applicable. The $p$ value $<0.05$ was accepted as level of significance. Statistical analyses were performed by using a computer based statistical program SPSS (Statistical package for social science) Version 22.0.

\section{Results}

Figures 1-3 show different levels of RBC, WBC and Platelet respectively in different groups.

\section{Discussions}

Table 1 shows, mean RBC count $(p<0.05)$ was found significantly increased in both groups, in comparison to that of their baseline values. There were also

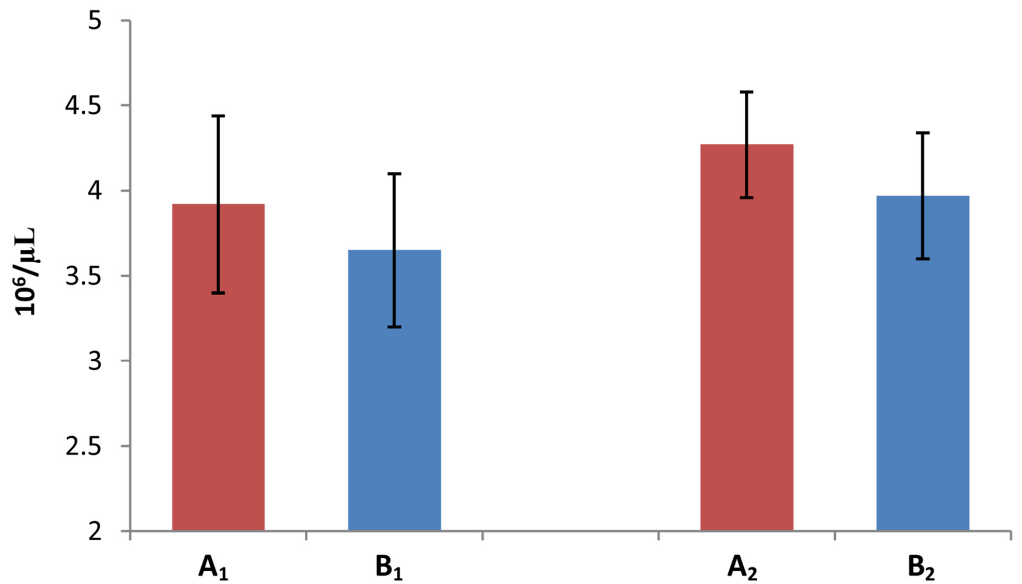

Figure 1. Mean total count of RBC in different groups $(n=43) . A_{1}$ : Study group (at baseline); $A_{2}$ : Study group (after 45 days of supplementation with amloki and iron tablet); $\mathrm{B}_{1}$ : Control group (at baseline); $\mathrm{B}_{2}$ : Control group (after 45 days of supplementation with iron tablet).

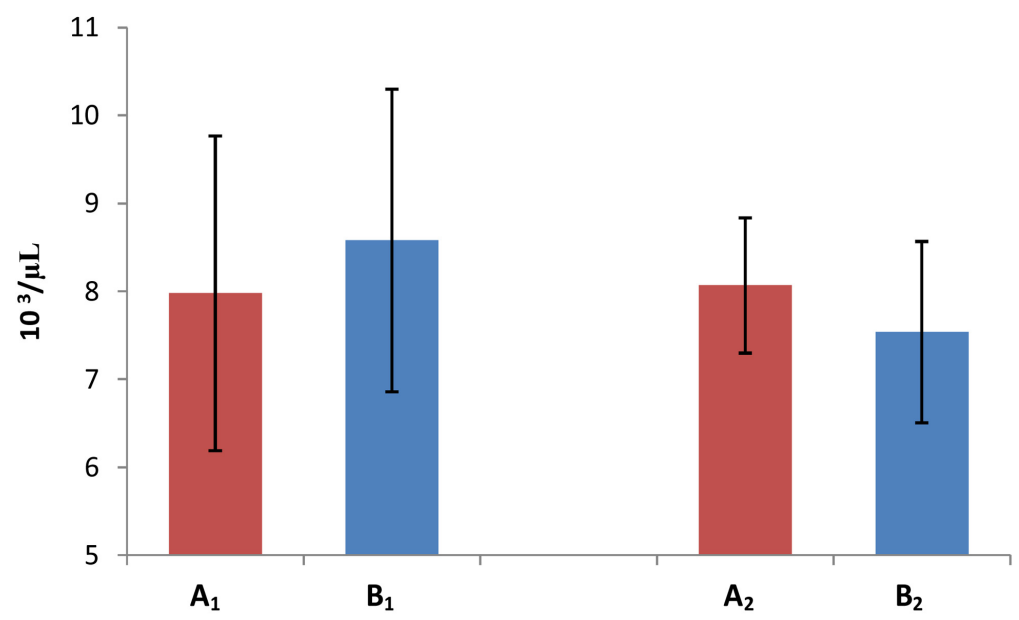

Figure 2. Mean total count of WBC in different groups $(n=43) . A_{1}$ : Study group (at baseline); $A_{2}$ : Study group (after 45 days of supplementation with amloki and iron tablet); $\mathrm{B}_{1}$ : Control group (at baseline). 


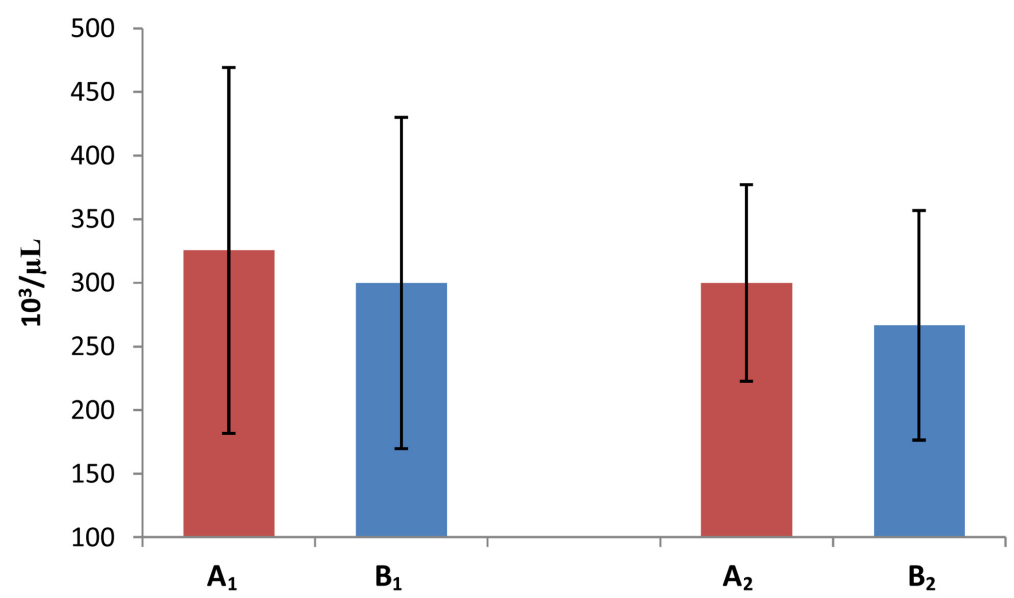

Figure 3. Mean total count of platelet in different groups $(n=43)$. $A_{1}$ : Study group (at baseline); $\mathrm{A}_{2}$ : Study group (after 45 days of supplementation with amloki and iron tablet); $\mathrm{B}_{1}$ : Control group (at baseline); $\mathrm{B}_{2}$ : Control group (after 45 days of supplementation with iron tablet).

Table 1. Haematological parameters in different groups $(n=43)$.

\begin{tabular}{|c|c|c|c|c|}
\hline \multirow{2}{*}{ Parameters } & \multicolumn{4}{|c|}{ Groups } \\
\hline & $\mathrm{A}_{1}(\mathrm{n}=24)$ & $\mathrm{A}_{2}(\mathrm{n}=24)$ & $\mathrm{B}_{1}(\mathrm{n}=19)$ & $\mathrm{B}_{2}(\mathrm{n}=19)$ \\
\hline $\mathrm{RBC}\left(10^{6} / \mu \mathrm{L}\right)$ & $3.92 \pm 0.52$ & $4.27 \pm 0.31$ & $3.65 \pm 0.45$ & $3.97 \pm 0.37$ \\
\hline $\mathrm{WBC}\left(10^{3} / \mu \mathrm{L}\right)$ & $7.98 \pm 2.09$ & $8.07 \pm 2.12$ & $8.58 \pm 3.45$ & $7.54 \pm 1.78$ \\
\hline Platelet $\left(10^{3} / \mu \mathrm{L}\right)$ & $325.6 \pm 143.8$ & $300.04 \pm 77.20$ & $300.0 \pm 130.2$ & $266.7 \pm 90.1$ \\
\hline \multicolumn{5}{|c|}{ Statistical analysis } \\
\hline \multirow{2}{*}{ Parameters } & \multicolumn{4}{|c|}{$p$ value } \\
\hline & $A_{1}$ vs $A_{2}$ & $A_{1}$ vs $B_{1}$ & $\mathrm{~B}_{1}$ vs $\mathrm{B}_{2}$ & $\mathrm{~A}_{2}$ vs $\mathrm{B}_{2}$ \\
\hline $\mathrm{RBC}$ & $0.009^{* *}$ & $0.081^{\mathrm{ns}}$ & $0.010^{*}$ & $0.007^{\star *}$ \\
\hline WBC & $0.870^{\mathrm{ns}}$ & $0.485^{\mathrm{ns}}$ & $0.313^{\mathrm{ns}}$ & $0.387^{\mathrm{ns}}$ \\
\hline Platelet & $0.453^{\mathrm{ns}}$ & $0.548^{\mathrm{ns}}$ & $0.346^{\mathrm{ns}}$ & $0.198^{\text {ns }}$ \\
\hline
\end{tabular}

Results are expressed as mean $\pm S D$. Paired " $t$ " test was performed for comparison within groups and Unpaired " $\mathrm{t}$ " test was performed to compare between groups. The test of significance was calculated \& $p$ value $<0.05$ was accepted as level of significance. $\mathrm{n}=$ number of subjects; $\mathrm{ns}=$ non significant; ${ }^{* * *}=$ significant. $A_{1}$ : Study group (At baseline); $A_{2}$ : Study group (After 45 days of supplementation with amloki and iron tablet); $B_{1}$ : Control group (At baseline); $B_{2}$ : Control group (After 45 days of supplementation with iron tablet).

significant increase in RBC count $(\mathrm{p}=0.007)$ in pregnant women supplemented with amloki and iron tablet in comparison to only iron supplemented group.

Almost similar types of results were observed by different researchers [5] [6] [17]. The increase in total count of WBC $(p=0.387)$ and decrease in total count of platelet $(p<0.198)$ in amloki and iron supplemented group was not statistically significant in comparison to only iron supplemented group.

Almost similar types of results were observed by different researchers [11] [18] [19].

Iron is found in ferrous/ferric form at the site of absorption of the intestine. 
Reduction of ferric to ferrous form is necessary for the absorption of iron. Ferric reductase (Dcytb) present on the brush border of enterocytes causes this reduction. Other dietary factor like vitamin $\mathrm{C}$ can also cause this reduction and enhance iron absorption. Vitamin $\mathrm{C}$ present in amloki is the most potent enhancer of iron absorption by its reduction to ferrous form [13]. Moreover, phytates present in cereals and legumes impair absorption of iron from foods as well as from soluble iron salts. Phytates form diferric and tetraferric phytates, which are insoluble in gastric environment [20]. Vitamin C can counteract the inhibitory effect of phytates by replacing it from iron and make iron soluble for better absorption [15]. This increased absorption of iron can cause increased erythropoiesis.

Other phytochemical properties of Emblica officinalis may play a role in erythropoiesis. It also contains other vitamins (vitamin- $A, K, B_{2}, B_{5}$ ), different minerals like iron, magnesium, potassium, zinc, copper, phenolic compounds (gallic acid, methyl gallate, gallic acid, trigallay glucose), amino acids (glutamic acid, proline, aspartic acid, alanine, cystine, lysine) [12] [21]. These phytochemicals are well known hemopoietic factors that have direct influence on the production of blood cells in the bone marrow [22].

Increasing in number of $\mathrm{WBC}$ may be a normal reaction to foreign substances. Amloki preparations may act as an antigenic substance that stimulates immune system and increase WBC count [11].

Moderate iron deficiency anaemia (IDA) is usually associated with reactive thrombocytosis. There are different possible causes of reactive thrombocytosis. In IDA there is increased rate of influx and efflux of precursor cells into the megakaryocyte compartment and shortening of megakaryocyte maturation. There is also stem-cell shunt due to inhibition of erythropoiesis, resulting in increased production of other pluripotent cells (haemostatic compensatory mechanism). In IDA free transferrin concentration is increased, which have stimulator effect on megakaryopoiesis. Thrombocytosis may disappear after iron supplementation as iron has an inhibitor effect on platelet counts [23]. Moreover, amloki is useful in reducing platelet counts. Flavonoids present in amloki, increase the cAMP levels in platelet, which is known to inhibit platelet activation by lowering intracellular $\mathrm{Ca}^{2+}$ levels [24] [25]. In this study, there was also decrease in platelet count which were not statistically significant.

\section{Conclusion}

After analyzing the results of the study, it can be concluded that combination of oral iron and Emblica officinalis (amloki) supplementation can cause significant increase in RBC count than that of only iron supplementation in pregnant women with iron deficiency anaemia.

\section{Acknowledgements}

The authors acknowledge Department of Pharmaceutical Chemistry, Faculty of 
Pharmacy and Department of Soil, Water and Environment, University of Dhaka for their kind cooperation.

\section{Conflicts of Interest}

The authors declare no conflicts of interest regarding the publication of this paper.

\section{References}

[1] Rupara, A.V., Donga, S.B. and Dei, L. (2013) A Comparative Study on the Effect of Pandughnivati and Dhatrilauhavati in the Management of Garbhinipandu (Iron Deficiency Anemia). Ayu, 34, 276-280. https://doi.org/10.4103/0974-8520.123120

[2] Huda, N.M., Mishra, D.S. and Singh, J.P. (2014) Clinical Evaluation of an Ayurvedic Preparation for the Treatment of Iron Deficiency Anemia in Patients. Journal of Homeopathy \& Ayurvedic Medicine, 3, 162.

[3] Idoate Gastearena, M.A., Gil, A.G., Azqueta, A., Coronel, M.P. and Gimeno, M. (2003) A Comparative Study on the Gastroduodenal Tolerance of Different Antianaemic Preparations. Human \& Experimental Toxicology, 22, 137-141. https://doi.org/10.1191/0960327103ht330oa

[4] Benjwal, S. (2013) Role of Amalaki (Emblica officinalis) Churna in Iron Deficiency Anemia in Pregnant Women. Ayurpharm International Journal of Ayurveda and Allied Sciences, 2, 48-51.

[5] Khandelwal, D.A., Donga, S.B. and Dei, L. (2015) Clinical Efficacy of Punarva Mandura and Dhatrilauha in the Management of Garbhini Pandu (Anemia in Pregnancy). $A y u, 36,397-403$. https://doi.org/10.4103/0974-8520.190700

[6] Khot, B.M., Patil, A.J. and Kakad, A.C. (2013) Comparative Clinical Study of Dhatri Lauha and Navayasa Lauha in Garbhini Panduroga with Reference to Anemia in Pregnancy. IOSR Journal of Dental and Medical Sciences, 11, 28-33. https://doi.org/10.9790/0853-1112833

[7] Terri, D., Wimbley, J. and Graham, D.Y. (2011) Diagnosis and Management of Iron Deficiency Anaemia in the 21 st Century. Therapeutic Advances in Gastroenterology, 4, 177-184. https://doi.org/10.1177/1756283X11398736

[8] Harper, J.L. (2020) Iron Deficiency Anemia Workup [Internet]. Web Med., New York. http:///emedicine.medscape.com/article/202333-workup

[9] Klemn, R.D.W., Sommerfelt, A.E., Boyo, A., Barba, C., Kotecha, P., Steffen, M. and Franklin, N. (2011) Are We Making Progress on Reducing Anemia in Women? United States Agency for International Development, Washington DC. http://www.a2zproject.org/pdf/ReducingAnemia_low_res_06212011.pdf

[10] Sharma, R., Jain, N., Rani, D., Jaitawat, A. and Kantawa, S.M. (2015) Role of Emblica officinalis and Foeiniculum vulgare during Pregnancy and Lactation. International Journal of Advanced Multidisciplinary Research, 2, 103-113.

[11] Sana, H. and Sinha, M.P. (2015) Effect of Emblica officinalis Fruit Extracts on Haematological Profile and Serum Lipid Variables of Albino Rats. Global Journal of Pharmacology, 9, 311-315.

[12] Dasaroju, S. and Gottumukkala, K.M. (2014) Current Trends in the Research of Emblica officinalis (Amla): A Pharmacological Perspective. International Journal of Pharmaceutical Sciences Review and Research, 24, 150-159.

[13] Scartezzini, P., Antognoni, F., Raggi, M.A., Poli, F. and Sabbioni, C. (2005) Vitamin 
C Content and Antioxidant Activity of the Fruit and of the Ayurvedic Preparation of Emblica officinalis Gaertn. Journal of Ethnopharmacology, 104, 113-118. https://doi.org/10.1016/j.jep.2005.08.065

[14] Venkatasubramanian, P., Koul, I.B., Varghese, R.K., Koyala, S. and Shivakumar, A. (2014) Amla Enhances Iron Dialysability and Uptake in In-Vitro Models. Current Science, 107, 1859-1864.

[15] Sharp, P. and Srai, S.K. (2007) Molecular Mechanisms Involved in Intestinal Iron Absorption. World Journal of Gastroenterology, 13, 4716-4724. https://doi.org/10.3748/wjg.v13.i35.4716

[16] Layeeq, S. and Thakar, A.B. (2015) Clinical Efficacy of Amloki Rasayana in the Management of Pandu (Iron Deficiency Anemia). Ayu, 36, 290-297.

https://doi.org/10.4103/0974-8520.182761

[17] Roy, A. and Dwivedi, M. (2014) Dhatrilauha: Right Choice for Iron Deficiency Anemia in Pregnancy. Ayu, 35, 283-288. https://doi.org/10.4103/0974-8520.153745

[18] Joshi, N., Dash, M.K., Dwivedi, L.K. and Khilani, G.D. (2015) Clinical Evaluation of Ayurvedic Iron (Lauha) Containing Preparations in Iron Deficiency Anaemia. International Journal of Research in Ayurveda and Pharmacy, 6, 225-231. https://doi.org/10.7897/2277-4343.06246

[19] Ramadevi, G., Jonah, S. and Prasad, U.N. (2014) A Clinical Study on the Effect of Dhatri Lauha in Garbhinipandu (Iron Deficiency Anaemia). International Journal of Research in Ayurveda and Pharmacy, 5, 708-712. https://doi.org/10.7897/2277-4343.056143

[20] Allen, L.H. and Ahluwalia, N. (1997) Improving Iron Status through Diet. In: Wagner, L.V., Ed., Relative Impact of Potential Interventions to Improve Dietary Iron Availability, Opportunities for Micronutrients Intervention, Washington DC, $1-86$.

[21] Yadav, V., Duvey, B., Sharma, S. and Devi, B. (2014) Amla (Emblica officinalis) Medicinal Food and Pharmacological Activity. International Journal of Chemical and Pharmaceutical Sciences, 3, 616-619.

[22] Okot-Asi, T.N.E., Chinaka, N.O., Ofem, O.E., et al. (2015) Effect of Moringa oleifera Lam. Ethanol Leaf Extract on Hematology in Phenyl Hydrazine Induced Anemic Albino Wister Rats. American Journal of Pharmacological Sciences, 3, 67-73.

[23] Kadikoylu, G., Yavasoglu, I., Bolaman, Z. and Senturk, T. (2006) Platelet Parameters in Women with Iron Deficiency Anemia. Journal of the National Medical Association, 98, 398-402.

[24] Roy, A.K.D., Gordon, M.J. and William, B.C. (1999) Inhibitory Effect of Ginco Biloba Extracts on Human Platelet Aggregation. Platelets, 10, 298-305. https://doi.org/10.1080/09537109975933

[25] Adebayo, A.H., Abolaji, A.O., Opata, T.K. and Adekbenro, I.K. (2010) Effects of Ethanolic Leaf Extract of Chrysophyllum albidum G. on Biochemical and Haematological Parameters of Albino Wister Rats. African Journal of Biotechnology, 9 , 2145-2150. 